\title{
Renata Šribar
}

\section{"IT'S NOT ADEQUATE, BUT OTHERWISE THEY WOULDN'T UNDERSTAND IT”: THE GENDER TAXONOMY REVISITED}

\begin{abstract}
The paper discusses the epistemic change in understanding the 'sex'/gender dichotomy and its deconstruction; conceptual developments have not been adequately implemented in the basic categorical gender apparatus and its usage promoted by the European Commission's studies and the integrated linguistic tools. The basic terms, sex and gender, are used interchangeably; even definitions where new concepts are introduced contradict each other. Mainstream gender policies have been slow in integrating new knowledge, although there is a trend to introduce a new gender category into the administration framework of EU states. The study aims at constituting the epistemic platform and a renewed gender related categorical apparatus to be used in the education sector. It resolves the inconsistencies present in various gender-focused studies by introducing the lowest common linguistic denominators supported by practical usage, EU political trends, and the contemporary epistemology of knowledge.
\end{abstract}

Keywords: 'sex'/gender, epistemic turn, terminological inconsistencies, corporeality, linguistic democratization

\section{"NI USTREZNO, TODA DRUGAČE NE BI RAZUMELE«: PONOVNI VPOGLED V TAKSONOMIJO SPOLOV - POVZETEK}

Prispevek obravnava spoznavni obrat v razumevanju dihotomije »biološki«/družbeni spol in izvedbi njegove dekonstrukcije; konceptualne nadgradnje v osnovnem kategoričnem aparatu, navezujočem se na spole in rabo terminov, se ne izvajajo ustrezno. Problematično je, da se nekonsistentnosti pojavljajo $v$ študijah in jezikovnem orodju, ki jih podpira Evropska komisija. Predhodno navedena osnovna izraza se v sintagmah uporabljata izmenično in poljubno; ob uvajanju sodobnih konceptov si nasprotujejo celo definicije v istem besednjaku. Vladajoče politike spolov so počasne pri vključevanju novih znanj, čeprav je v EU opazen trend uvajanja nove spolne kategorije v okviru upravljanja držav. Pričujoča študija je namenjena oblikovanju spoznavne platforme in prenovi kategoričnega aparata, ki bi se lahko uporabljal v izobraževalnem sektorju. Nedoslednosti različnih študij o spolih preči z uvedbo najmanjših skupnih jezikovnih imenovalcev. Te potrjujejo življenjske prakse, politični trend $v$ EU in sodobna epistemologija vednosti.

Ključne besede: »biološki «/družbeni spol, epistemski preobrat, terminološka neskladja, telesnost, lingvistična demokratizacija

Renata Šribar, PhD., Centre FemA - Institute of transformative studies, renata.sribar@ guest.arnes.si 


\section{EXPOSITION}

The basic hypothesis accompanying the spectrum of gender related categories presented here is consistent with Simone de Beauvoir's ambivalence towards gendered corporeality and social gender roles and statuses. Are their bodies, the actual physiological and anatomic phenomena, the fundamental reason for the discrimination of women? Or have gender-biased interpretations of bodily characteristics induced discrimination and exclusion? It may be noticed that the very term 'gendered' (in the Slovene language, ospoljeno), attached to corporeality ('gendered corporeality'), provides the answer. It rewrites Simone de Beauvoir's (2000) famous statement that a woman is not born, that she is construed. 'Sexe' is included in the original title of her transformative work, Le deuxième sexe, which implies that women, according to her arguments, are not biologically determined but socially construed by discourses. Being alive and working on her book nowadays, Simone de Beauvoir would have entitled the book Le deuxième genre, taking into account the conceptualization of the categorical pair sex/gender in the period from the early till the mid-1970s (Oakley, 1992; Rubin, 1995).

From the 1980s the concepts of sex/gender were theoretically revisited during the major epistemological development of feminist thought (Butler, 1990; Haraway, 1991). If 'sex' is related to the body and 'gender' to the social realm, there is always the possibility of making this relationship causal. In that case, women's bodies would already predestinate women's lives: discursively, the universalized woman's body is often used as an argument to justify gender discrimination. When the two concepts are no longer closely associated with the nature/culture divide, this deconstruction leads us to think beyond a discursive body, i.e. embodied genders as social construction. Gender norms, prescriptions, social myths, and cultural idioms are revealed as agents on the corporeal level; discourse is active in a body; according to our knowledge, it is transformed into bodily discourse, into a discourse of the body itself (Šribar, 2004). ${ }^{1}$

Following this major epistemic shift in interdisciplinary and transdisciplinary women's and gender studies and feminist theory, the question becomes: which discourses related to gendered bodies are liberating, and which gender myths, phrases, and argumentations are oppressive? To conclude these introductory thoughts, the hypothesis proffered is this: what is invested in discriminatory and exclusion practices on the basis of gender is interpretations. The core of interpretations are concepts, i.e. sex/gender (biološki/družbeni spol), women/men, female, male, queer, transgender/transsexual - and their specific usages.

1 On Menstruation: The Body in Discourse, Discourse in the Body [the original title of the book in Slovene is $O$ menstruaciji: telo v diskurzu, diskurz v telesu] (Šribar, 2004) is the study of the anthropology and sociology of menstruation. Among several results revealing gendered biased (negative) interpretations of reproductive women's bodies, the most important one was the thesis that discourses on menstruation affected menstrual health. Prostaglandins, physiologically produced chemicals, cause contracts of the uterus. The excessive production of prostaglandins often has no physiological cause, and the anthropological and sociological research relate menstrual taboos, prohibitions, and the stigmatization of menstruation (even in its subtler forms, e.g. in ads) as a discursive issue in the menstrual malfunctioning of the body. 
In the discussion that follows, the gender taxonomies of European Union institutions are presented and analyzed using semiotic and critical discourse analysis tools, enlivened with some auto-ethnographic input. Further on, some epistemic insights and practical linguistic suggestions are presented with the aim of finding a common platform for a possible consensual gender categorization, at least in certain benevolent research and pedagogic environments. Some accompanying education practices are suggested, having in mind a gender-aware perspective in pedagogical and other information-disseminating activities in adult education.

\section{TERMINOLOGICAL AND CONCEPTUAL GENDER/SEX AMBIVALENCES IN OFFICIAL KNOWLEDGE DISSEMINATION IN THE EU}

Part of the EC's (European Commission's) research and innovation initiatives, the 7th Framework Programme included the area of gender. One of the successful projects of the so called Capacities programme was titled "Gender in research as a mark of excellence", and it was carried out by the Belgian-French enterprise Yellow Window. Policy design is promoted as one of the services, and the project has actually been applicative in character as regards gender knowledge and awareness of gender dimensions in research and related sectors' services, e.g. health. Among the EU-wide workshops, the Slovenian one was dedicated to the basic knowledge of the gender perspective, and it was carried out at the Ministry of Tertiary Education, Science, and Technology (now the Ministry of Education, Science, and Sport). Unaware of the level of presentation, some members of the Commission for Women in Science took part, mostly researchers and lecturers in the SSH (social sciences and humanities) field, with either good or excellent expertise in gender studies and feminist theory. The other half of the participants was from the STEM (natural sciences, technology, engineering, and mathematics) field, and interested in the gender perspective in research as well. The lecturer and moderator of the workshop explained the difference between the two concepts, sex and gender, in their uncritical and outlived modus. She was asked if it had been adequate to ignore the feminist criticism of the ideologically biased biological interpretations of gendered corporeality, mainstreamed as the concept 'sex'. The Yellow Window representative claimed that the participants of the workshop educated and employed in STEM wouldn't be able to understand the deconstruction of the sex/gender divide from the contemporary perspective, critical of the biology and its biased gender interpretations. ${ }^{2}$ Her statement was impolite, probably out of embarrassment because she had been openly criticized. Some colleagues, probably also including chemistry researchers, heard the humiliating answer to the provoking critical question, which had been put forward by my colleague from the Commission for Women in Science, and myself. Thus the construction of the sex/gender divide was once again confirmed and ready to be reproduced as part of the ignorance phenomena, classified as "we do not want them to know, because we don't want to complicate our lives" (comp. Tuana, 2006). The interpretation of the discussed divide can still be found on the Yellow Window home page.

2 Personal archive (notes on communication taking place during the workshop pause, 16 ${ }^{\text {th }}$ March 2012). 
Sex refers to the biologically determined characteristics of men and women in terms of reproductive organs and functions based on chromosomal complement and physiology. As such, sex is globally understood as the classification of living things as male or female. Gender refers to the social construction of women and men, of femininity and masculinity, which varies in time and place, and between cultures.

The notion of gender appeared in the seventies and was put forward by feminist theorists who challenged the secondary position of women in society. It departs from the notion of sex to signal that biology or anatomy is not destiny. It is important to distinguish clearly between gender and sex. These terms are often used interchangeably but they are conceptually distinctive. (source 1: Gender in EU founded research, n. d.)

\section{The construction of knowledge on gender(s) and the production of ignorance}

There is transparent and often experienced incompatibility between the two fields of knowledge that deal with the socio-cultural production of genders, feminist epistemology/theory, and sociological gender studies, which draw their reliability mostly from quantitative survey and mixed methods research. The lack of joint disciplinary projects, at least in Slovenia, affects the way gendered discourses are marginalized, or mainstreamed. In-depth epistemological reflections need decades to be implemented in the epistemic framework of empirical research or are perhaps never implemented. But when certain concepts are integrated - in our case, the sex/gender categorical combination - the implications of application are not very clear. The confusion, proven by the existence of certain vague syntagms (explored later in the article), is actually suitable for those of us who argue against the indicated conceptual divide. At the same time, one has to bear in mind that more than forty years ago, it was useful to indicate the socio-cultural and political technologies of gender by inventing 'gender', to promote the sex/gender divide, and to explain the recognizable ways we become women and men.

To discuss the vague use of the terms sex/gender, four publications from an EC's gender-related personal collection (regularly acquired in the years from 2010 until today) have been selected and indicated here as sources: a tool-kit (source 1), two policy-implementing studies (sources 2 and 3), and the EC-supported gender glossary (source 4). The aim of the analysis is to reveal the discursive matrix implied in the sex/gender dichotomy ambivalences that reveal themselves. Both disciplinary fields, SSH and life sciences, produce gender-related knowledge - and ignorance - primarily by way of (mis)understanding 'sex' (biološki spol), sex-related corporeal categories, and their relation to gender.

Let us continue with the strangest syntagm encountered in the study of the four sources (source 2: Structural change in research institutions: Enhancing excellence, gender equality and efficiency in research and innovation, 2012), "sex discrimination" (p. 8). Although it is known that the inquiry into discrimination prevailingly defines 'gender' (not sex) as 
one of its bases, the term 'sex' is used here. It is difficult to imagine how 'sex' seems the proper categorical solution, as discrimination is one of the social acts construing 'gender'. Discrimination and gender are co-constitutive. Checking the Yellow Window definition of the term sex again, the use of the word in the syntagm 'sex discrimination' has a symbolic impact, which is itself discriminatory. Women and girls, indicated by the term 'sex', are hereby presented as biologically destined corporeal identities. According to the Yellow Window definition of the word 'sex', they are symbolically and in imagination enclosed in or are at least close to the common kingdom of living females regardless of the species (source 1: Gender in EU founded research, 2012). Because of the popular mytheme that "males ruling over females is natural", gender-based violence is or may be perceived as natural. The socio-cultural, political, and economic conditions of gender hierarchy, discrimination and exclusion are not sufficiently thematised in public. The cultural fantasies of 'alpha males' and 'weak submissive females' are perpetuated, and the only power acknowledged is physical and instinctive. Consequentially, critique of discrimination could be regarded as an unreasonable intervention in the 'true', 'essential' nature of the two 'sexes' .

In the Slovenian lexicon, we are fortunate that the word spol can be used in both senses, that of corporeality, and that of social constructivism. The Slovenian term samica (indicating female, and clearly defining with the very term her/its role in the reproductive mechanism) can be used only for animals. Critically examining source 2, the EC publication Structural change in research institutions (2012) further, a typically vague and freely interchangeable use of sex/gender could be found in terms such as: "sex/gender variable", "sex-disaggregated data"; "women researchers", "female scientists"; "gender disaggregated data", "sex/gender results and methods" (p. 13, 27, 37, 38, 39 in the respective order). Gathered from these examples is proof that there is no unambiguous epistemic tool available to distinguish the two categories as regards their integration in these phrases. As all the enumerated word groupings are contextualized by the inquiry into the statuses, roles, and opportunities of women in research, it is contradictory to the aim of the research to position and reduce the respondents to 'the females', because they are already construed as 'the social other', the ones who are dominated, and are of lesser societal importance. 'Sex' in such context might have been the proper term decades ago. 'Sex', like in de Beauvoir's Second Sex, was the only available term to refer to the social groups of women and men.

Another publication produced by the EC and published recently (source 3: Report on equality between women and men in the EU, 2018) already uses the word 'female' in the

3 Twenty-two years ago, I was invited to present a lecture on gender at a regular meeting of the Ljubljana AA, an alcoholics anonymous group lead by a well-known medical doctor. While talking about sexual harassment and gendered socio-cultural relations supporting the victimization of the victim, one of the men commented that it was normal for men to commit sexual offence acts, even rape, if it happened to be springtime. His argument was that this is what animals do. While his attitude was at the far end of the sexual violence ideological spectrum, the matrix is the naturalisation and normalisation of violent and offensive acts against women's integrity - the other end of the spectrum being the seemingly flattering side of sexual harassment (Personal communication during the workshop at the AA meeting, Ljubljana Clinical Centre, 1996). 
contents section, in the function of an adjective: "female labour market". The connotation is ascribing gendered characteristics to the market of jobs offered to women, occupied by women, declined to them - and besides, the main reference is the perpetuation of the gender-specific structuring of employment and work conditions. It is again obvious that the implied generalization is based on the socio-cultural and political construction of the women and work relation. The inadequate choice of term is accompanied by a misleading, yet seemingly self-evident interpretation. The dominant idea, accepted by the moral majority, is the naturalization and normalization of women's employment conditions and career opportunities. It is related to supposedly universal corporeal characteristics, which at the lowest common denominator comprise the visual impression of being a woman. It's not only about employment and work practices related to women's corporeality (sex-appeal, reproductive phenomena, claims regarding image at work). There is also the widely used and not problematised concept, one which pejoratively naturalises poor working conditions in employment sectors that are prevailingly occupied by women: 'feminization'. The elements that make up the 'female labour market' are well-known: unequal payment, women as the major social group among the unemployed, gendered professional segmentation, women slavery, the glass-ceiling and the snowball effect as part of the hindrances to career development, discriminatory and even illegal claims regarding image, ageism, expected 'feminine' behaviour and even women's 'culture' 4 , informal social duties, sexual harassment from superiors and co-workers, and so on. The word 'female' is here not only a symptom of the discriminatory conditioning of the labour market, it is part of the syndrome comprised of the humiliating and oppressing situations and discourses women are exposed to at work, yet not in general terms and not all of them by default, since gender may also function as the untypical positioning of a person, e.g. the traditional female positioning may be occupied by a man or vice versa. The enumerated characteristics describe the work conditions and disadvantages that are systemically and structurally (institutionally) possible and likely to occur mostly to women, which means not only to women, and not to all of them. As can be seen in the following lines, the comparable phrase to the 'female labour market' is the wording 'employment opportunities for women', where according to the same logic, 'female employment opportunities' could be also used but is not, as there would be some hidden logic in relating the words 'female labour'/'women's employment'. The syntagm 'female employment in transport' is found here. The inexact or vague, and inconsistent usage of gender/sex terms and the related categories (female, male, man, woman) has been amply proven. As regards the plausible meanings arising from conscious or unconscious androcentric intentions to dominate, some further analysis has been done.

Further discussion on the ideological matrix of the terminological ambivalences emerges rather spontaneously. Obtaining the indicative wording by checking more than half of

4 The claim for sustaining 'women's culture' was articulated by one of the men members of the Slovenian Commission for Women in Science during the 2010 - 2014 mandate (Personal archive, Communication at one of the commission meetings in 2011). 
source 3, The report on equality between women and men in the EU (2018), publication pages (p. 8, 35, 36, 37, 42, 44, 46, 47, 48), the phrases are arranged below with the aim of testing the hypothetical inscription of biased gender structuring in the use of 'sex' or 'gender'. Two groups are formed, (A) comprising of phrases with sex/female/male categories, and (B) with the term 'gender' in the syntagms.

Group A: female labour market / female chair / female networks / female trafficking victims / female politicians / female victims of sexual violence / male offenders / female employment in transport.

Group B: gender pay gap / women employment rate / cyber violence against women and girls / women human rights defenders / gender-based violence / women's access to justice / gender perspective / physical and psychological integrity of women / refugee women / women's political participation / employment opportunities for women / disadvantage of women / women in transport.

The term 'female' is as a rule used only as an adjective, never as a noun. It appears much less frequently than the term 'women', posited as a single or compound noun, where it has the function of a gender marker. In three out of eight cases, it characterizes the domain or structure ('labour market', 'employment in transport', 'networks'). 'Female' is used twice in the traditionally atypical pairing with a high career rank and a seemingly privileged men's profession (a chair, politicians). The phrase 'woman chair' and 'women politicians' would render this rank and profession more appropriate on the imaginative level, as the word 'female' associates the position and job with less serious occupational engagement. Twice it is linked to traditionally heavily subjected women's roles ('trafficking victims', 'victims of sexual violence'). Those two examples are in textual and symbolic proximity with 'male' dominance ('offenders'). When the words 'female'/'male' are used in such discursive constellations in a universalized crime setting - women victims/men offenders -, it naturalizes and normalizes the relation; if 'gender' is used, the implication is different, indicating gendered criminal realities, without automatically reproducing the ideology inscribed in the adjectives 'female'/'male'. To make an inference, the whole picture reflects traditional gender role modelling: with the adjective 'female', the structures and positions are implicitly characterized by traditionally biased gendering or, when the position or structure is traditionally associated with men, the link to 'femaleness' renders it less attractive, not as serious as it should be, or unlikely to be adopted by women in numbers.

'Gender' and 'women' are mostly integrated in the syntagms which sound or are read in accordance with a contemporary gendered human condition: always when women are addressed as members of a certain societal group, or when they are participants/respondents in research. Other uses are related to technology, and human/women's rights discourse.

Beside inexact and incoherent intertwining of 'sex' and 'gender' terms, and the nouns in the syntagms, the socio-cultural contextualization proves the obsolete character of the notion of 'sex' in the discussed strategic, research and education frameworks. Later in the 
study, 'sex' is going to be analysed in different social and epistemic contexts with the aim to examine the possibility of its (direct) relation to corporeality itself, uncontaminated by socio-cultural and strategic or ideological investments. For the moment, in discussing the terminological side of contemporary gender-knowledge relations, 'sexed' bodies are perceived discursively - they are considered social bodies, hologram entities in the realm of the symbolic.

\section{An auto-ethnographic starting point to the discussion on corporeality}

The only body that is substantive here is the author's, but it is restricted as well by the images, habits, and convictions of itself. As such it cannot be freed from being imaginarily and symbolically embedded in various hologram-like locations of intersected perspectives; it never appears in isolation as a 'sexed' body alone.

'Ain't I a woman' is part of the title of a famous book by bell hooks (1982). It is used as a political rhetorical question, with the body as the constructed platform of social relations. It is never devoid of them, there is no way for it to escape socialisation, which begins in the uterus, in the moment when the ultrasound reveals whether "it's a girl" or "it's a boy". There is no body which is not subjected to norms and hidden or transparent prescriptions. Although bell hooks thematizes and critically analyses 'race' and ethnicity relations, the body and the embodied experiences are never those of the 'females', human beings with the 'female' sex essence, which would make them embodied totalities. Critical thinking on this originates in women's groups, which were socio-culturally and politically marginalized in complex ways on the basis of REI - ideas and practices of 'race', ethnicity, imperialism, class, and gender. Because of the supremacy of middle-class white women in the globalized feminist movements and theories of that time, 'sex' (as a category still used in the 1970s) comes in as a challenged concept, challenged mostly and primarily by 'race' and class.

Theories, ideas, ideologies, and ordinary phrases discursively construct our realities, yet they are never out of the body; it cannot be said that words and other carriers of meaning are destined to have their dead end somewhere where flesh, veins, neurons, molecules, genes, and hormones come in. On the other hand, words have their final destination - just like live bodies, i.e. bodies that we can touch and feel in a way we have been taught to. The fulfilment of the verbal - the symbolic, and the imaginary deeds is in their impact not only on bodies, but in them. In the presented reflexive context, I have found - as a feminist anthropologist of everyday life - what the ultimate message of the Yellow Window workshop lecturer received by the women in STEM disciplines was. They took in her explanation of the sex/gender schism word for word, although it was declared obsolete by us, women humanists, and they could not do otherwise, because contemporary

$5 \quad$ As stated by Momin Rahman and Stevi Jackson (2010), this is a citation, a refrain from a famous speech that Sojourner Truth, a former slave, gave in Ohio in 1852. She made the category of sex unstable by presenting her body as one that was as able as a man's body and receiving none of the social comforts that white middle class women did. 
gender knowledge was denied to them. Instead of an explanation of the reason behind such definitions, they experienced humiliation. The sentence "It's not adequate [to base a gender lecture on the conceptualization of the sex/gender schism], but they would not understand it otherwise" was communicated to women intellectuals, and the message affected more than their mind - in the accompanying emotional response their bodies were hurt as well. In this mental, emotional and somatic intertwining, were I in their shoes, I would read the sentence as "you are embodied impossibility of becoming a subject of the elaborated knowledge". Let me connect the relation of words, meaning and body on the broader socio-political level. The described ideas inherent in the indicated vague or false and misleading syntagms using the term 'female' are not innocent agents of our realities. For example, let us take education as one of the characteristically 'female' employment sectors. 'Female', like 'feminization', in words and practices discursively structures jobs sectors in a way that make them less desirable for men - with the exception of high-ranking positions. 'Female' and 'feminized' mean degraded via the traditional gender myths of the 'natural' gender order. Not that we could do much by using the terms 'gender' and 'women' in all the previously analysed syntagms instead of 'sex' and 'female', but there is a denotative implication which associate the term 'gender' with at least a bit of dignity, a possibility of change for the better.

\section{Is it possible to avoid the vague gender terminology in the EC gender policies framework?6}

Personally experiencing the governmentality in the EC domain, it would be fair not to blame the Yellow Window lecturer for unintentionally humiliating the participants who work in STEM during the Ljubljana gender in research workshop. The project "Gender perspective in research" followed the EC guidelines on the sex/gender conceptualization (see an adaptation of the EC source by Kozmik and Mrak Thorne, 1998). The ignorance of more evolved gender knowledge, developing at the time when the guidelines were published, was produced on a higher level. To stick to the facts, Yellow Window went a step further from the EC official sex/gender concepts, wherein the term 'sex' was interpreted as biological characteristics which divide human beings according to dimorphism, and 'gender' was interpreted in causal relation to sex (literally, "social manifestation of sex", glossary entry "gender", ibid). At least the inherent connection between 'sex' and 'gender' has been abandoned (see the previously cited Yellow Window definitions). The new proposal of the Europe-wide gender thesaurus and glossary was elaborated in 2015 (Neubauer and Šribar, 2015), and was revised and published by the end of 2016 or at the beginning of 2017 (source 4, Gender Equality Glossary and Thesaurus). Because the lead person of our expert team has been integrated into UN and EU structures, and the commissioner was the EC institution EIGE, it was impossible to avoid the traditionalism and rigidity in defining the entry 'sex' - and to introduce contemporary explanations of the

6 The answer to the question asked in the subtitle, for the time being, is no. This is only logical considering the categorical and conceptual inconsistencies which are continually reproduced by slight changes because of the introduction of the new concepts. 
sex/gender categories implemented in feminist epistemology and gender studies, the first in the 1980s, and then the 1990s. Having no control over the final version of the glossary (and being responsible only for the proposal of a Europe-wide gender thesaurus), I was unable to prevent the contradiction between the definition of 'sex', and the introduction and definition of 'intersex'. "Sex" is still understood in terms of corporeal dimorphism, but "intersex" introduces factual corporeal ambiguities as regards reproductive anatomy and physiology (Gender Equality Glossary and Thesaurus, entries "sex" and "intersex"):

Sex: Biological and physiological characteristics that define humans as female or male.

Intersex: Umbrella term to denote a number of different variations in a person's bodily characteristics that do not match strict medical definitions of male and female.

Similarly, the definition under the entry "gender" does not correspond to other entries of related definitions which transgress the gender dichotomy (Gender Equality Glossary and Thesaurus, entries "gender", "queer", "third gender", "transgender", and "transsexual"):

Gender: Social attributes and opportunities associated with being female and male and to the relationship between women and men and girls and boys, as well as to the relations between women and those between men.

Queer: All individuals who fall outside the gender and sexuality 'norms'.

Third gender [no definition but included as additional notes and information]: Queer theory and civil movements - focused on alternative gender or transgender/transsexual identity, traditional praxes and knowledge of the 'third' gender - together initiated a new administrative and statistical category, beyond the binary opposition of woman/man (or female/male). It has been introduced in New Zealand and Germany (as 'indeterminate/unspecified' gender), and in India, Bangladesh and Pakistan either as the gender category of 'other', or 'third gender'.

Transgender: Person who has a gender identity different to the gender assigned at birth and who wishes to portray identity in a different way to the gender assigned at birth.

Transsexual: Person who prefers another gender than the birth gender and feels the need to undergo physical alterations to the body to express this feeling, such as hormone treatment and/or surgery.

Contemplating the inconsistencies inherent in the very definitions, and in comparing them, these cannot be treated as coincidences: the 'sex' and 'gender' definitions are in accordance with the UN ones, which can be checked in the entries' sources. The implied 
mental rigidity is related to duality ideologies, which renders the world in a comfortable interpretative framework, characteristic for the so called Western religious and intellectual tradition. 'Sex' is framed in the dimorphism of male/female, 'gender' in the dichotomy man/woman. ${ }^{7}$ In the EIGE glossary, the close relation between 'sex' and 'gender' is sustained, although it is not as strong or directly causal as in the definition of 'gender' in the previous glossary formally confirmed at the highest administrative level of the EU (adapted for Slovenia by Kozmik and Mrak Thorne, 1998). According to the definition of 'gender', bodies are not gendered by biology and medicine as we claim they are; gender is supposed to be something secondary to the 'sexed' corporeality; it is described like a kind of socio-cultural dress for women and men. All research of bodies being 'sexed' in a gender biased way by biology and medicine is ignored. To adopt the relatively novel 'sex' and 'gender' dichotomy interpretation, multi-level argumentation against gender biased science must be recognized as the thorough feminist epistemological input (see also Maksimović, Ostrouch Kamińska, Popović in Bulajić, 2016, pp. 9-10). Specific features of the wished for acknowledgment of gender blind or biased life sciences should be: the lack of any sex indicator which is not exposed to corruption in the course of the development of human beings - or which is not falsely presented in dominant scientific and popularized discourses on the two 'sexes': gonads, hormones, chromosomes, physiology, anatomy are flexible and not unambiguously sex specific; the absence of interdependency between morphology and function; the impact of discourse on corporealities; the false or misleading animal sex metaphors; large cross-sections of the features of women's and men's bodies. This is actually the shortest possible basic summary of biologist and feminist Ann Fausto-Sterling's reference book on sex and gender in society (2012).

Another ideological connotation beside the obsolete character of the definitions under the entries on 'sex' and 'gender' which is hard to ignore, is the lax attitude towards gender-based discrimination - as though this was not inscribed in traditional gender construing. "Attributes" and "opportunities" are the only mentioned societal (and cultural, political) dimensions of the two genders in the cited definitions. The cited EIGE definitions of 'queer', 'third gender', and even 'transgender' and 'transsexual' persons are all related to gender identity categories, which oppose the EIGE gender definition. Although different sources define 'transgender' and 'transsexuality' in diversified ways, the stress here is not on these discrepancies. But there is another inconsistency of interest to be considered once more: the already well-known vagueness and inconsistency in the usage of the terms 'sex' and 'gender' are also detected in a number of phrases. In order to compare the 'sex' and 'gender' syntagms, most of the EIGE glossary phrases with these two terms are cited below:

7 The philological insight itself, without any feminist epistemological, sociological, anthropological and gender studies knowledge, reveals the imbalance inscribed in the word pairings: female is 'the other' of male, woman 'the other' of man. There is no symbolic topos explicating equality, because the prefixes to the root words 'male' and 'man' make the 'female' nouns function symbolically as a Biblical rib of Adam - a little something attached or belonging to males/men is what designs females/women. 
sex and gender based discrimination, sex bias in data collection, sex-disaggregated data, sex-disaggregated statistics, sex-role stereotypes, sex stereotypes, sex trafficking, sexual division of labour; gender analysis, gender balanced participation, gender based bullying, gender based discrimination, gender based division of labour, gender based violence, gender discrimination, gender division of labour, gender identity, gender pay gap, gender quota, gender reassignment, gender roles, gender segregation, gender statistics, gender violence [...] (Gender Equality Glossary and Thesaurus).

Some phrases use the terms 'sex' and 'gender' interchangeably, without exact and conclusive logic: "sex-role stereotypes", "gender roles", "sex bias in data collection", "sex-disaggregated data", "sex-disaggregated statistics", "gender statistics", "sexual division of labour", "gender division of labour".

Other phrases are difficult to understand for various reasons: "sex and gender-based discrimination", "gender discrimination" - they lack persuasiveness, first, of distinguishing between sex discrimination and gender discrimination, and second, of using both combinations once in a pair of phrases, and once in a separate phrase. Another ambiguity arises from the uncertain meanings of the terms 'sex' and 'sexual' in English: why the need for "sexual division of labour" if there is a more appropriate 'gender' phrase? In the case of medical transformation, "sex reassignment" may be appropriate, but "gender identity" might be misleading because it refers to gender self-identification; anyway, in state administrative practices, we are used to identifications as regards sex and gender markers assigned at birth. In administrative language both terms are interchangeable.

Auto-ethnographic note. The critical analysis of the EIGE glossary is meant to be constructive, aimed at future improvements, the possibility of which is suggested on the web page as well. I was as the co-author of the proposal of the glossary in question, and as such responsible, too. I tried hard to introduce the notions of 'queer', 'transgender' and 'intersex', which was not easy, but successful at the end of the day. After that, I had no real structural power to promote and help implement new definitions of sex and gender in accordance with contemporary feminist epistemology and gender studies theory. It became clear to me only later on that huge conceptual inconsistencies were caused by the strategy of "something old and something new". Besides, I share responsibility for the vague 'sex' and 'gender' phrases. I worked with others on the first glossary proposal and probably overlooked certain inexact solutions, being individually responsible only for the thesaurus (Šribar, 2015). The second proposal of the glossary, which was approved by EIGE, was mostly finalised without my participation. The point of this summary of auto-ethnographic remembering, notes, and my personal archive of e-mails, is to draw attention to power hierarchies. Despite the quite adequate participation of EIGE staff, the processing of the task had been characteristic for the contemporary structuring of work: acceleration of time - time pressure, poor resource management in general, not enough 
cooperation with the stakeholders, no true monitoring of the process, not enough expert supervision, and probably also a certain lack of specific knowledge.

What is interesting is the technology of reproducing the described circumstances on the individual level. In spite of one's efforts, there are hindrances to even the best work practices, which according to personal experiences could be defined as: strong institutional hierarchies, shortcomings in staff either in terms of numbers, competences or work ethics norms, ambitions which do not correspond to expected competences, competences which often cannot be obtained because of the time pressure, deadlines which cannot reasonably be argued, the need or greed for public and institutional success, professional status and references, and financial resources.

\section{THE OPTIMIZATION OF THE GENDER TAXONOMY, AND RELATED TERMINOLOGY: THE SLOVENIAN EPISTEMIC AND LEXICAL EXAMPLE}

\section{On democratic linguistic solutions}

Although the Slovene language is much more flexible and at least partially more democratic in regard to the grammatical and lexical expression of gender, the insensible impact of English grammatical and lexical solutions may be detected in numerous cases of scientific, expert and public discourse. The strangest Slovene language 'innovation' is the use of the noun with the feminine suffix together with the noun 'women' (ženske) placed in front of it. The word 'women' is in the position of the adjective. No such usage as ženske profesorice is correct when indicating 'women professors' or the like. The combination of two nouns becomes even more linguistically problematic when the noun ženske is used with another noun in the masculine grammatical form: ženske profesorji. A further example of nearly unbelievable exploitation of the natural language can be found in the Slovene translation of one of the EC's gender publications (Razlike med spoloma pri izobraževalnih dosežkih: Študija o položaju v Evropi in sprejetih ukrepih, 2010): profesorji ženskega spola, 'professors of female [grammatical] gender' (p. 98).

If linguistic copying went in the opposite direction, from Slovene to the globalized English language, only 'gender', 'gendered' (in Slovene basic categories 'spol', 'spola', 'spo$l i$ ', 'ospoljen/-a/-o') would be used in nearly all of the terms that have been singled out above. That would be a most welcome solution. The argumentation is complex:

- Corporeality cannot be directly addressed. Not only the verbal but also every other discourse, praxis included, has symbolic meaning by which we mentally and emotionally grasp the material world. In other words, corporeality is always mediated, meaning that from the theoretical viewpoint it is never sexed, it is always gendered.

- A body is transformed according to cultural practices and environmental conditions, which are in themselves substantial and influential when it comes to corporeality. More than that, it is transformed by discourses, which are unsubstantial but echo in corporeality anyway. The meanings get embodied, what is societal and cultural is inscribed on the body surface and below it. The bodies are therefore characterized by 'plasticity'. 
- Biological and medical knowledge are time-place conditioned; these domains are prey to different interests, which are nowadays mostly focused on social status and benefits, and financial capital. The interpretations of bodies are thus gendered in the ways which are not at all transparent. There is no innocently sexed body, all we can get in the domains we work in are the scientifically, expertly gendered bodies.

- The category and contemporary conceptualization of genders deconstruct corporeal/'sex' dimorphism, and societal gender dichotomy. There is an observable number of persons who identify themselves as transgender. This is the umbrella category under which all people who are born out of bodily dimorphism or are not willing to identify as women or men are gathered. The new categorical apparatus of genders has been already suggested by A. Finn Enke (2012, p. 244): women, men, transgender (persons). These categories are suitable for epistemic, educational, state administrative, and public/(new) media use.

In the Slovene language medical and other disciplinary references to corporeality are gendered by the nouns and adjectives moški, ženske, moško, žensko (men/men's, women/ women's, man/man's, woman/woman's). In English expressions, 'womanlike', 'womanly' and 'manlike', 'manly' are used in the same textual contexts. By privileging plural forms the inadequate generalization of the gendered bodies is not possible; in the education and health sector this is very important.

In literal translation from Slovene, English 'sex' could exist only when denoting matter related to sexualities (spolnost, seksualnost, seksualno, spolno). With the presented conceptualizations of the terms 'gender' and 'sex', the ambiguities in meanings of 'sex'/'sexual' when translating English into Slovene would be avoided.

\section{Some future research-oriented thoughts on genders and bodies}

Hypothesis. After decades of gender constructivism in opposition to historical (sex) essentialism and biologism bodies are again in focus from a different perspective. Corporeality is legitimate in the strategic gendering of women when some ultimate gender-based discrimination is in question.

Renowned feminist scholar Judith Butler asserts that feminism is passé as the only common denominator of the political subject of the social group of women left is the body in pain; women's suffering bodies are the new constitutive base for feminism (2004) if it is to politically and theoretically survive. In recent years the Slovenian school of feminism and psychoanalysis opened the discussion on a kind of new essentialism, which refuses to be identified as such. Eva D. Bahovec (2011) relates the 'lacking' corporeality (i.e. weak and unrecognized women's presence) to women's impossibility of being (acknowledged) philosophers, subjects of philosophy: "If I am a woman, I cannot be a philosopher." (p. 208) The condition of this negative professional existence is legitimate as long as women are not able to transform the philosophic canon. In accordance with psychoanalysis, this implicitly relates to the masochistic positioning of women, and the deconstructivism of Catherine Malabou (2011). 
Malabou, who was a successful student of Derrida, later diverged into philosophic autonomy, problematising the status of women philosophers. What is important to our discussion is her elaboration of the 'return to the body', which in its argumentation is evidently not essentialist. Women's bodies in philosophy (let's add: and elsewhere in privileged androcentric domains and situations) are marked by the impossibility of achievement, and that emotionally as well as somatically hurts. To make the conclusion: in the new epistemic confirmations of corporeality, its mediated nature is not and cannot be wholly deconstructed. Judith Butler's women's bodies in pain, Eva Bahovec's and Catherine Malabou's women's bodies reflecting impossibility, are made substantial by that very pain. At the same time, women's bodies are construed by society, and the various ways it produces hurtful obstacles to the realization of women's wishes, intentions, talents, etc., and last but not least importantly, life lust and love. Yet according to Malabou (2011), it is possible to start anew from women's 'essence', compounded of aching corporeality, and symbolic societal violence, represented in her work by the disciplinary rigidity and androcentrism of philosophy. With the aim to transgress the symbolic violence inscribed in women's bodies there is "no need to decline concepts" (p. 167), she writes. But we may, as is already well-known, re-conceptualize them. Hopefully we have accomplished some work here by trying to improve the gender-related categorical apparatus in English and Slovene.

\section{CONCLUSION}

The applicative value of the suggested improvements to the basic gender glossary in formal and informal education

According to Joanna Ostrouch-Kamińska and Cristina C. Vieira (2015), there is still a lack of gender perspective and gender related research in adult education, a "worrisome omission considering the fact that one of the principles of the field is to raise awareness of people, foster critical thinking and help combat discrimination." (p. 6) Although genders are still considered here in gender dichotomy ("women and men"/"men and women") there's hope for a more just, genders reflecting world of "open, plural, multicultural, personalized and egalitarian community" (ibid., p. 188). The development starts with education on gender equality (ibid., p. 188). This meta-aim of their study invites us a bit further, concretely to think, feel and act in the novel framework as tertiary education teachers, researchers, educators and active citizens, who have an impact on children and younger people. The platform is revealed:

- first, by deconstruing the sex/gender divide and implementing a corresponding gender related categorical apparatus, inclusive of 'transgender';

- second, by trying to cope with the gendered obstacles to human wellbeing without investing in hurtful activities or an internalization of a discriminatory environment; instead of that, the option is mutual support, especially when the wellbeing and self-realizations of women and transwomen are in question. 
There are many trends and currents in gender studies and feminist theory, and often they oppose each other, or are inconsistent in mutual juxtapositioning. The decision about which epistemic conceptual framework is to be placed in a dominant position has to be grounded on solid facts and the new epistemology of knowledge. From that angle the present study refers to a reality check (intersex and trans-persons phenomena), the EU socio-political trend of introducing a new gender category beside man/woman, and the epistemic framework deconstructing the androcentric paradigm of knowledge and its production which has also been confirmed by the so called hard sciences (neuroscience, physics of elementary particles).

\section{REFERENCES}

Bahovec, D. E. (2011). Od Hegla do ženske. In C. Malabou, Bodi moje telo! Dialektika, dekonstrukcija, spol (pp. 189-215). Ljubljana: Krtina.

Beauvoir, S. de (2000). Drugi spol. Ljubljana: Delta.

Butler, J. (1990). Gender Trouble: Feminism and the Subversion of Identity. London: Routledge.

Butler, J. (2004). Undoing Gender. New York and London: Routledge.

Fausto-Sterling, A. (2012). Sex/Gender: Biology in a Social World. New York and London: Routledge.

Finn Enke, A. (2012). The Education of Little Cis: Cisgender and the Discipline of Opposing Bodies.

In S. Stryker and A. Aizura (Eds.), The Transgender Studies Reader (pp. 234-247). New York and London: Routledge. Retrieved from https://www.researchgate.net/publication/283366414_The_education_of_little_cis_Cisgender_and_the_discipline_of_opposing_bodies.

Gender Equality Glossary and Thesaurus. (n. d.). Retrieved from http://eige.europa.eu/rdc/thesaurus.

Gender in EU founded research. A tool-kit. (n. d.). Retrieved from https://docs.wixstatic.com/ugd/17c073_39e67c6a2c3e4e9183fd9d64892fcecd.pdf.

Haraway, D. (1991). Simians, Cyborgs, and Women. New York: Routledge.

hooks, b. (1982). Ain't I a Woman: Black Women and Feminism. London: Pluto Press.

Kozmik, V. and Mrak Thorne, M. (1998). 100 besed za enakost: slovar izrazov o enakosti žensk in moških [adapted translation of 100 Words on Equality, European Commission]. Ljubljana: Vlada Republike Slovenije, Urad za žensko politiko.

Malabou, C. (2011). Bodi moje telo! Dialektika, dekonstrukcija, spol. Ljubljana: Krtina.

Maksimović, M., Ostrouch-Kamińska, J., Popović, K. and Bulajić, A. (Eds.) (2016). Editorial Introduction: Philosophy, History, Practice, and Gender Research in Adult Education. In M. Maksimović, J. Ostrouch-Kamińska, K. Popović and A. Bulajić (Eds.), Contemporary Issues and Perspectives on Gender Research in Adult Education (pp. 9-20). Beograd: Institute for Pedagogy and Andragogy, Faculty of Philosophy, University of Belgrade. Retrieved from content/uploads/2016/12/Appendix4ESREAbookMaksimovicetal2016.pdf.

Neubauer, V. and Šribar, R. (2015). First draft Europe-wide gender equality glossary. Vilnius: European Institute for Gender Equality.

Oakley, A. (1972). Gender, Sex and Society: Towards a New Society. London: Temple Smith.

Ostrouch-Kamińska, J. and Vieira C. C. (2016). Introduction: Gender and World(s) of Informal Learning; Informal Learning and Gender. In J. Ostrouch-Kamińska and C. C. Vieira (Eds.), Private World(s): Gender and Informal Learning of Adults (pp. 1-12; 183-190). Rotterdam: Sense. Retrieved from https://www.sensepublishers.com/media/2281-private-worlds.pdf. 
Rachman, M. and Jackson, S. (2010). Gender and Sexuality: Sociological Approaches. Cambridge and Malden: Polity Press.

Razlike med spoloma pri izobraževalnih dosežkih: Študija o položaju v Evropi in sprejetih ukrepih [Gender Difference in Education Outcomes: Studies on the Measures Taken and the Current Situation in Europe]. (2010). Ljubljana: Ministrstvo za šolstvo in šport.

Report on equality between women and men in the EU. (2018). Luxembourg: European Commission. Retrieved from https://publications.europa.eu/en/publication-detail/-/publication/950dce57-6222-11 e8-ab9c-01aa75ed71a1/language-en.

Rubin, G. (1975). The Traffic in Women: Notes on the Political Economy of Sex. In E. Lewin (Ed.), Feminist Anthropology: A Reader (pp. 157-210). Hoboken, New Yersey: Blackwell.

Structural change in research institutions: Enhancing excellence, gender equality and efficiency in research and innovation (2012). Brussels: European Commission, Directorate General for Research and Innovation. Retrieved from https://ec.europa.eu/research/swafs/pdf/pub_gender_equality/ structural-changes-final-report_en.pdf.

Šribar, R. (2004). O menstruaciji: telo v diskurzu, diskurz v telesu [On Menstruation: The Body in Discourse, Discourse in the Body]. Ljubljana: Delta.

Šribar, R. (2015). First draft Europe-wide gender equality thesaurus. (Updated and approved version). Vilnius: European Institute for Gender Equality.

Tuana, N. (2006). The Speculum of Ignorance: The Women's Health Movement and Epistemologies of Ignorance. Hypatia 21(3), 1-31. Retrieved from https://muse.jhu.edu/login?auth=0\&type=summary\&url=/journals/hypatia/v021/21.3tuana02.html. 